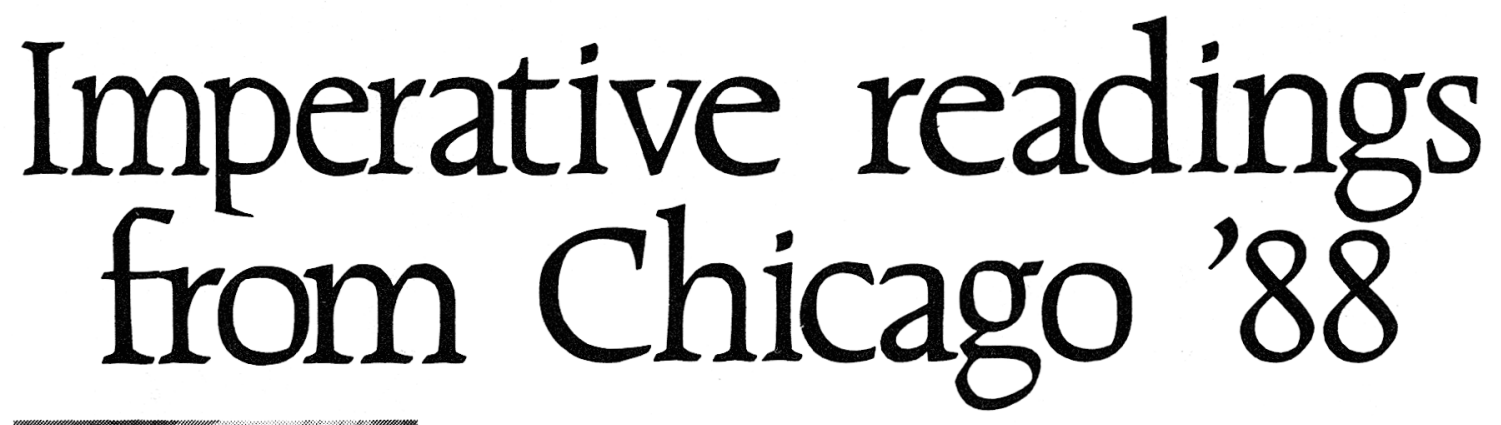

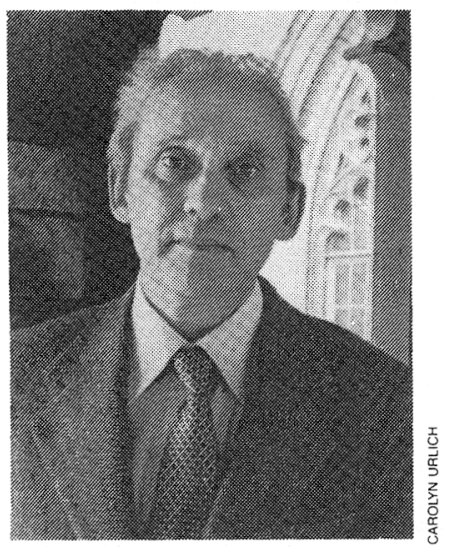

The final volume-

TIME AND NARRATIVE

Volume 3

PAUL RICOEUR

Translated by Katbleen Blamey and David Pellauer

Reexamining and synthesizing his ideas about the relations between time and narrative in historical writing, fiction, and theories of literature, Ricoeur presents a complete and satisfying statement of his own philosophy, "the best kind of philosophy." (Eugen Weber, New York Times Book Review) Cloth \$29.95 368 pages

Also available-

VOLUME 1

Cloth $\$ 25.00288$ pages

VOLUME 2

Cloth $\$ 25.00216$ pages

\section{THE TRIAL(S)}

\section{OF PSYCHOANALYSIS} Edited by FRANÇOISE MELTZER

The fourteen essays in this collection make psychoanalysis the object of inquiry in an attempt to find its proper place among other modes of thinking. Contributors include Jean Starobinski, Stanley Cavell, Jane Gallop, Michael Riffaterre, and Ernesto Laclau.

Paper $\$ 13.95302$ pages

Library cloth edition $\$ 28.00$

\section{SOWING THE BODY}

Psychoanalysis and Ancient

Representations of Women

PAGE DUBOIS

Foreword by Catharine R. Stimpson

DuBois' radically new examination of women in classical Greece both draws on and challenges the traditions of psychoanalysis and classical studies and those of feminist, literary, and Marxist theory to imagine new wavs of thinking about the place of the female in ancient culture. Cloth \$29.95 248 pages 15 balftones

WOMEN IN CULTURE AND SOCIETY SERIES

\section{JEAN-JACQUES \\ ROUSSEAU}

Transparency and Obstruction

JEAN STAROBINSKI

Translated by Arthur Goldhammer

Introduction by Robert J. Morrissey

"Remarkable. ... such a wealth of reflections that we learn not only about Rousseau but about the distinctive qualities of the literature that was born with him." - Maurice Blanchot, Le Livre à venir

Paper $\$ 19.95464$ pages

Library cloth edition $\$ 60.00$

Also by Jean Starobinski

MONTAIGNE IN MOTION

Translated by Arthur Goldhammer

Paper $\$ 14.95360$ pages

Library cloth edition $\$ 30.00$

\section{THE LETTERS OF MACHIAVELLI}

A Selection

Edited and Translated by

ALLAN GILBERT

"A specialist's competence, added to a strong historical-stvlistic sensibility, make [Gilbert] the ideal translator of Machiavelli's letters." -G. Velli, Italian Quarterly

Paper $\$ 9.95252$ pages

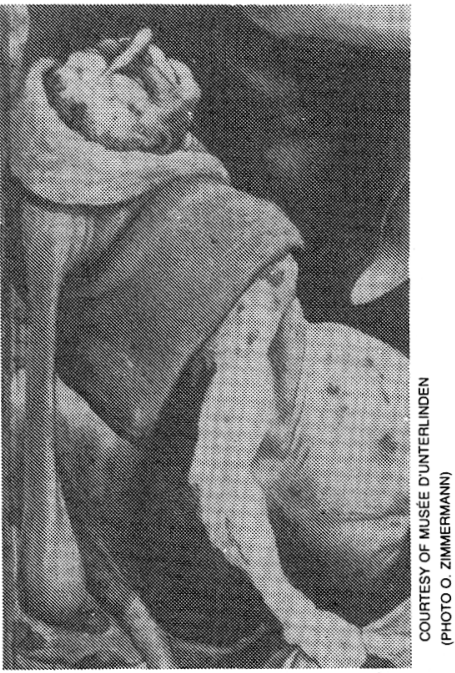

\section{THE ASCETIC IMPERATIVE IN CULTURE AND CRITICISM} GEOFFREY GALT HARPHAM

"An extraordinary text, interweaving its passionate learning between the church fathers and contemporary thought with equal relevance."-Mary Ann Caws, City University of New York

Cloth \$29.95 336 pages 27 balftones

THE SURPRISING EFFECTS OF SYMPATHY Marivaux, Diderot,

Rousseau, and Mary Shelley

DAVID MARSHALL

"An impressive achievement. In a series of acute readings, Marshall reveals the centrality of the notion of sympathy for major eighteenth-century texts. He locates the ways in which accounts of sympathy as a natural tendency innate to humans quickly become involved with a fear that sympathy may not be natural enough."-Frances Ferguson, University of California, Berkeley Cloth \$27.50 296 pages 1 balftone 


\section{LLUMINATING LITERARY STUDIES}

\section{TIMELY READING \\ Between Exegesis and Interpretation}

By SUSAN NOAKES. Noakes challenges the notion of "timeless" works of literature and a historically unchanging reading process.

"Offers illuminating, often brilliant readings

of key texts about reading from turning

points in the fourteenth and nineteenth

centuries."-William J. Kennedy, Cornell

University. Ready in July. $\$ 29.95$

\section{LITERARY KNOWLEDGE \\ Humanistic Inquiry \\ and the Philosphy of Science}

By PAISLEY LIVINGSTON. In a world where the model of knowledge is generally drawn from the natural sciences, what does "literary knowledge" mean? Responding to this question, Livingston addresses the science/humanities dichotomy that is such a central concern of teaching and research today. $\$ 9.95$ paper; $\$ 29.95$ cloth

\section{SOCIAL SEMIOTICS}

By ROBERT HODGE and GUNTHER KRESS. The authors show how semiotics may be integrated into the analysis of power, ideology, class and gender. "A splendid introduction to the study of signs and signification." - Graham McCann, King's College, Cambridge University. Illustrations. \$14.95 paper; $\$ 47.50$ cloth

\section{FICTIONS OF THE FEMININE \\ Puritan Doctrine \\ and the Representation of Women}

By MARGARET OLOFSON THICKSTUN. Thickstun explores the influence of Puritan theology and domestic theory on the representation of women in English literature, focusing on Spenser's Faerie Queene,

Bunyan's Pilgrim's Progress, Milton's Paradise Lost, and two later novels, Richardson's Clarissa and Hawthorne's The Scarlet Letter. $\$ 19.95$

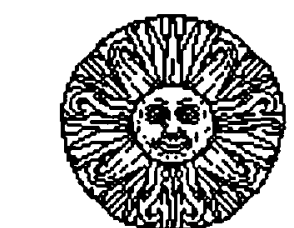

CORNELL UN IVERS ITY PRES S 124 Roberts Place, Ithaca, NY 14850
NAMING THE ROSE

Eco, Medieval Signs, and Modern Theory

By THERESA COLETTI. "Naming the Rose identifies and examines the current theoretical issues embodied by Eco in his novel, clarifying at the same time these issues and Eco's book." - Larry S. Crist, Vanderbilt University. \$19.95. Ready in June.

\section{PROPHESYING TRAGEDY \\ Sign and Voice in Sophocles' \\ Theban Plays}

By REBECCA W. BUSHNELL. Bushnell asserts that an understanding of tragic fate, as represented in prophecy, can be achieved through an awareness of the historical relationship of tragedy to culture and politics. $\$ 18.95$

\section{FOXES AND LIONS \\ Machiavelli's Confidence Men}

By WAYNE A. REBHORN. This book connects Machiavelli's literary works with his political and historical writings, and relates all of them to his life history, his concerns with power and powerlessness, and his characteristic modes of self-representation. $\$ 24.95$

\section{RHETORICS OF \\ REASON AND DESIRE \\ Vergil, Augustine, and the Troubadours}

By SARAH SPENCE. "[Spence's] analysis of Vergilian, Augustinian, and troubadour rhetoric-and of the relative authority of reason and will implicit in each-sheds important new light on the evolution of language theory and its social context during a crucial millennium of European civilization."-Robert W. Hanning, Columbia University. $\$ 22.50$

\section{TO MAKE A POET BLACK}

By J. SAUNDERS REDDING. With a new introductory essay by Henry Louis Gates, Jr. First issued in 1939, this work is a classic study of Black American poetry from the late eighteenth century to the Harlem Renaissance by a scholar who has been a major figure in Black Studies for two generations. $\$ 22.50$ cloth; $\$ 6.95$ paper 